\title{
Acylated Flavone Glycosides from the Roots of Saussurea lappa and Their Antifungal Activity
}

\author{
Kolisetty Sambasiva Rao*, Goriparthi Venu Babu and Yemireddy Venkata Ramnareddy
}

School of Studies in Chemistry, Vikram University, Ujjain, M.P. India- 456010

* Author to whom correspondence should be addressed: E-Mail: ksrao7709@rediffmail.com; Tel. (+91)-09282155564.

Received: 14 November 2005; in revised form: 20 February 2007 / Accepted: 21 February 2007 / Published: 7 March 2007

\begin{abstract}
The isolation of four novel acylated flavonoid glycosides from the roots of Saussurea lappa and their identification using a combination of 1D and 2D NMR and mass spectrometry is described. The in vitro antifungal and antibacterial activities of the isolated compounds and their mixture were tested on nine fungal and four bacterial strains, using the microdilution method. The compounds and mixture showed moderate to high antifungal activity against most of the fungi tested, compared to a miconazole standard, while only one compound and the mixture showed antibacterial activity against all strains tested.
\end{abstract}

Keywords: Saussurea lappa, acylated flavone glycosides, scutellarein, kaempferol, antifungal acitivity.

\section{Introduction}

Saussurea lappa C.B. Clarke, syn. S. costus (Falc) Lipsch (Asteraceae) is a Himalayan species that occurs at elevations from 2,700-4,000 m in Kashmir, Lahul Valley in Himachal Pradesh and Garhwal in Uttranchal [1-2]. The roots possess carminative, analgesic, anthelmintic and emmenagogic properties, stimulate the brain and cure blood diseases and liver and kidney disorders. They are prescribed in advance stages of typhus fever, rheumatism, nervous disorders, irregular menstruation, heart diseases, to improve complexion, as a hair wash to kill lice and to turn grey hair to black [3-5]. It 
contains lappadilactone and seven sesquiterpene lactones as cytotoxic principles against selected human cancer cell lines. Lappadilactone, dehydrocostuslactone and costunolide exhibited the most potent cytotoxicity with CD50. Seven noncytotoxic compounds were also isolated, including two novel sesquiterpenes, a guaianolide type with a C17 skeleton, lappalone and 1 $\beta, 6 \alpha$-dihydroxycostic acid ethyl ester [6]. (E)-9-Isopropyl-6-methyl-5,9-decadiene-2-one, a terpenoid C14-ketone, lupeol palmitates, $\alpha$-amyrin starate, $\beta$-amyrin from the costus leaves [7-8], 4- $\beta$-methoxydehydrocostuslactone [9], the sesquiterpenoid saussureal [10], amino acids, saussureamines A-E, the lignan glycoside (-) massoniresinol-4"-O- $\beta$-D-glucoside [11], two guaianolides, isodehydrocostus lactone and isozaluzanin-C and two sesquiterpene lactones with an $\alpha, \beta$-unsaturated aldehyde group [12] are other reported compounds from Saussurea lappa. This paper describes the isolation and characterization of four new flavonoids KSR1-KSR4 from the roots of the plant.

\section{Results and Discussion}

The compounds KSR1-KSR4 were isolated by repeated chromatography (column and HPLC) of a flavonoid fraction obtained by processing of an ethanolic extract of powdered, dry S. lappa roots.

KSR1

KSR1 was obtained as a yellow amorphous powder with negative optical rotation $\left[[\alpha]_{D}{ }^{15}-46.9^{\circ}\right.$, C $\left.=0.10 ; \mathrm{MeOH}_{-} \mathrm{H}_{2} \mathrm{O}(1: 1)\right]$. Its UV spectrum showed maxima at 378, 344, 300 and $210 \mathrm{~nm}$, indicating its polyphenolic nature. The HR-FAB-MS exhibited a pseudomolecular ion $[\mathrm{M}+1]^{+}$at $\mathrm{m} / \mathrm{z}$ 965.32, compatible with the molecular formula $\mathrm{C}_{45} \mathrm{H}_{56} \mathrm{O}_{23}$ (calc. 964.15333). This was in good agreement with the presence of six methyl, three methylene, 21 methine and 15 quaternary carbon resonances in its ${ }^{13} \mathrm{C}-\mathrm{NMR}$ and DEPT spectra. Its ${ }^{1} \mathrm{H}-\mathrm{NMR}$ spectrum (Table 1 ) displayed five aromatic protons at $\delta_{\mathrm{H}}$ 7.12 (d, $J=8.7 \mathrm{~Hz}$ ), 7.44 (d, $J=2.3 \mathrm{~Hz}$ ), 7.55 (dd, $J=8.7 / 2.3 \mathrm{~Hz}$ ), 6.79 (s) and 6.98 (s), which indicate the presence of one $\mathrm{ABX}$ system and two non-correlated aromatic protons, respectively. This suggested that KSR1 might be a $5,6,7,3^{1}, 4^{1}$ or $5,7,8,3^{1}, 4^{1}$ pentasubstituted flavone derivative. Since the signal at $\delta_{\mathrm{C}} 102.89$ was assigned to the C-3 position in the flavone aglycone according to its ${ }^{3} J_{\mathrm{HC}}$ and ${ }^{2} J_{\mathrm{HC}}$ correlations in the HMBC spectrum and the published data for flavone glycosides [13], the signal at $\delta_{\mathrm{C}} 93.70$ was attributed to the A-ring. The differentiation on the basis of the A-ring methine resonance between the 5,6,7 (scutellarein-type) and 5,7,8 (isoscutellarein-type) trioxygenation patterns has been previously reported [13]. According to this finding, the presence of an aromatic methine carbon signal $\left(\delta_{\mathrm{C}} 93.70\right)$ in the $\delta_{\mathrm{C}} 90.0$ - 96.0 range indicates a non-substituted C-8. Furthermore, a correlation was observed between the $\delta_{\mathrm{H}} 3.88$ methoxy proton singlet signal and C-4' of the benzoyl group $\left(\delta_{C} 151.10\right)$ in the HMBC. In addition to this there is a peak at $\delta_{C} 132.7$ that represents the cyclopentene ring in the compound [14] and there is an HMBC cross peak for C- $1 \mathrm{a}^{\prime}$ of the cyclopentene ring at $\delta_{\mathrm{C}} 113.3$ and $\mathrm{C}-3^{\prime}$ at $\delta_{\mathrm{C}} 152.9$, which indicates the attachment of the cyclopentene ring at C-3'. A peak at $[43+\mathrm{Na}]^{+}$(loss of acetic acid) in the HR-FAB-MS suggested the flavonoid having an acetate [15], which was supported by the presence of carbonyl peaks at $\delta_{\mathrm{C}} 172.5$ and $\delta_{\mathrm{C}} 74.2$ for an acetyl attached carbon in the ${ }^{13} \mathrm{C}-\mathrm{NMR}$. In the ${ }^{1} \mathrm{H}-\mathrm{NMR}$ a significant singlet peak at $\delta_{\mathrm{H}} 2.06$ for the methyl in $\mathrm{CH}_{3} \mathrm{COO}$ - was also observed. The ${ }^{1} \mathrm{H}$-NMR spectrum showed sharp singlets at $\delta_{\mathrm{H}} 1.21$ 
and 1.21; these two peaks represent gem-methyl groups associated with the cyclopentene ring [16]. The broad doublet peak at $\delta 5.02$ for olefinic proton $\left(\mathrm{H}-2 \mathrm{a}^{\prime}, J=2.5 \mathrm{~Hz}\right.$ ) by HSQC. A triple doublet (ddd) appearing at $\delta_{\mathrm{H}} 5.12$ was assigned to H-3a $\beta^{\prime}\left(\mathrm{J}_{3 \mathrm{a} \beta^{\prime}, 4 a \alpha^{\prime}}=12.8 \mathrm{~Hz}, J_{3 \mathrm{a} \beta^{\prime}, 4 \beta \mathrm{a}^{\prime}}=4.9 \mathrm{~Hz}, J_{3 \mathrm{a} \beta^{\prime}, \mathrm{H}-2 \mathrm{a}^{\prime}}=2.5\right.$ $\mathrm{Hz}) \mathrm{HMBC}$ from the already published data [16]. A triplet at $\delta_{\mathrm{H}} 1.34\left(J_{4 \alpha \mathrm{a}^{\prime}, 4 \beta \mathrm{a}^{\prime}}=J_{4 \alpha \mathrm{a}^{\prime}}, 3 \beta \mathrm{a}^{\prime}=12.8 \mathrm{~Hz}\right)$ due to coupling with the $\mathrm{H}-3 \beta \mathrm{a}^{\prime}$ (HMBC) and special interactions with $\mathrm{H}-2 \mathrm{a}^{\prime}$ (ROE) was assigned to $\mathrm{H}-4 \alpha \mathrm{a}^{\prime}$. The partially simplified multiplets between $\delta_{\mathrm{H}}$ 1.94-2.0 suggested that the signals for $\mathrm{H}-4 \beta \mathrm{a}^{\prime}$ were localized in this region. Cross peaks were observed in C-3' and C-1a', C-3' and C-2a', C-2a' and $\mathrm{H}-3 \beta \mathrm{a}^{\prime}, \mathrm{H}-3 \beta \mathrm{a}^{\prime}$ and $\mathrm{H}-4 \alpha \mathrm{a}^{\prime}, \mathrm{H}-3 \beta \mathrm{a}^{\prime}$ and $\mathrm{H}-4 \beta \mathrm{a}^{\prime}, \mathrm{C}-3 \mathrm{a}^{\prime}$ to $\mathrm{O}-\mathrm{C}=\mathrm{O}$ and from all these data we deduced that the cyclopentene ring was attached at C-3' of the flavonoid. From the above discussion we concluded that the nucleus of KSR1 was a scutellarein flavone glycoside derivative. Furthermore, the correlation observed between the methoxy proton signal as a singlet $\delta_{\mathrm{H}} 3.88$ and C-4' of the benzoyl group $\delta_{C} 151.10$ in the HMBC spectrum led us to determine the aglycone moiety as 3'-(3R-acetoxy5,5-dimethylcyclopent-1-ene)-4'-O-methylscutellarein, as shown in Figure 1.

Figure 1. Structures of isolated compounds KSR1-KSR4.

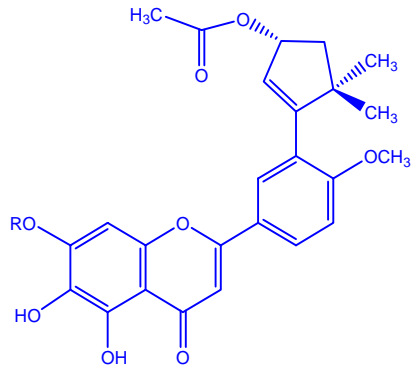

KSR1
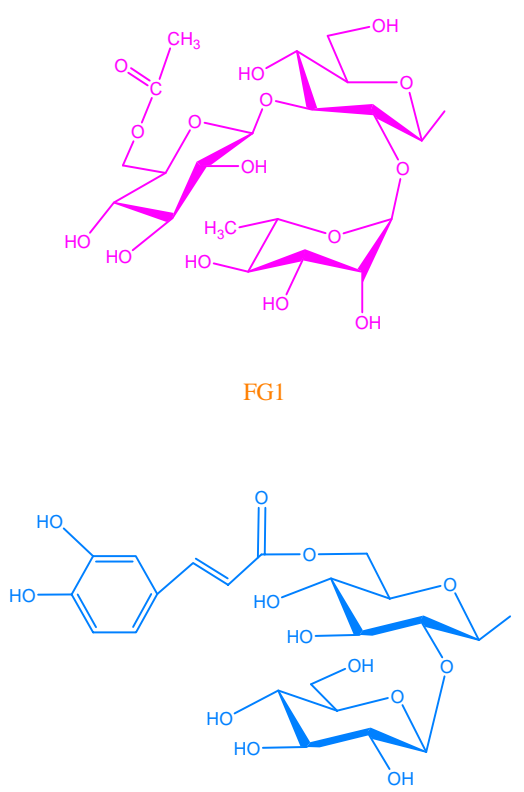

FG3<smiles>O=c1c(O)cc(O)cc2oc(-c3ccc(O)cc3)c(O)c12</smiles>

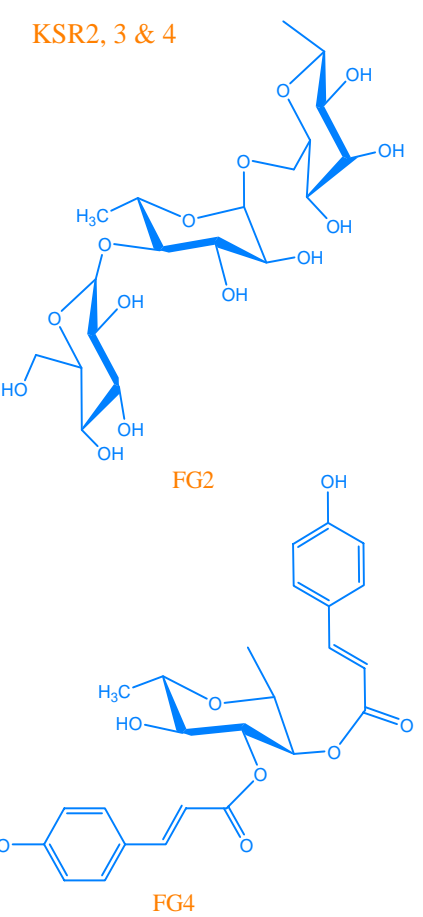


Table 1. ${ }^{13} \mathrm{C}-(125 \mathrm{MHz})$ and ${ }^{1} \mathrm{H}-\mathrm{NMR}(500 \mathrm{MHz})$ spectral data for KSR1* $\left(\mathrm{D}_{2} \mathrm{O}\right)$.

\begin{tabular}{|c|c|c|c|c|c|}
\hline $\mathbf{C} / \mathbf{H}$ & $\boldsymbol{\delta}_{\mathrm{C}}$ & $\delta_{\mathrm{H}}(\mathrm{m}, \boldsymbol{J} \mathbf{H z})$ & $\mathbf{C} / \mathbf{H}$ & $\boldsymbol{\delta}_{\mathrm{C}}$ & $\delta_{\mathrm{H}}(\mathrm{m}, J \mathrm{~Hz})$ \\
\hline \multicolumn{6}{|c|}{ Aglycone } \\
\hline 2 & 163.84 & & $8 a$ & 105.58 & \\
\hline 3 & 102.89 & $6.79(\mathrm{~s})$ & $\mathbf{1}^{\prime}$ & 123.01 & \\
\hline 4 & 182.12 & & $2^{\prime}$ & 112.86 & $7.44(\mathrm{~d}, 2.3)$ \\
\hline $4 a$ & 148.78 & & $3^{\prime}$ & 146.78 & \\
\hline 5 & 146.78 & & $4^{\prime}$ & 151.10 & \\
\hline 6 & 130.75 & & $5^{\prime}$ & 112.01 & $7.12(\mathrm{~d}, 8.7)$ \\
\hline 7 & 150.87 & & $6^{\prime}$ & 118.60 & 7.55 (dd, 8.7, 2.3) \\
\hline 8 & 93.70 & $6.98(\mathrm{~s})$ & $\mathrm{OCH}_{3}$ & 55.71 & $3.88(\mathrm{~s})$ \\
\hline \multicolumn{6}{|c|}{ 3'-cyclopent-1-ene } \\
\hline $1 \mathbf{a}^{\prime}$ & 158.20 & & $5 \mathbf{a}^{\prime}$ & 26.30 & \\
\hline $2 a^{\prime}$ & 132.70 & $5.02(\mathrm{~d}, 7.2)$ & $3 a^{\prime}-\mathrm{CO}$ & 168.3 & \\
\hline $3 a^{\prime}$ & 74.20 & 5.12 (ddd,12.8, 4.9, 5) & $\mathrm{CO}-\underline{\mathrm{CH}}_{3}$ & 18.7 & $2.06(\mathrm{~s})$ \\
\hline $4 \mathbf{a a}^{\prime}$ & 29.60 & 1.94 (m, dd, 12.8) & $5 \mathbf{a}^{\prime}-\alpha \mathrm{CH}_{3}$ & 16.5 & $1.12(\mathrm{~s})$ \\
\hline $4 \mathbf{a} \beta^{\prime}$ & 29.60 & 1.66 (m, dd) & $5 \mathbf{a}^{\prime}-\boldsymbol{\beta C H}_{3}$ & 16.5 & $1.12(\mathrm{~s})$ \\
\hline \multicolumn{6}{|c|}{ 7-O-glucopyranosyl } \\
\hline $\mathbf{1}^{\prime \prime}$ & 97.27 & $5.49(\mathrm{~d}, 7.3)$ & $5^{\prime \prime}$ & 76.85 & $3.25(\mathrm{t}, 9.8)$ \\
\hline $2^{\prime \prime}$ & 76.53 & $3.81(\mathrm{~d}, 9.4)$ & $6^{\prime \prime}$ & 60.89 & $3.44(\mathrm{dd}, 12.0,6.0)$ \\
\hline $3^{\prime \prime}$ & 86.63 & $3.73(t, 9.4)$ & $\mathrm{OCOCH}_{3}$ & 20.38 & $1.94(\mathrm{~s})$ \\
\hline $4^{\prime \prime}$ & 68.14 & $3.44^{\dagger}$ & $\mathrm{OCOC \textrm {H } _ { 3 }}$ & 170.04 & \\
\hline \multicolumn{6}{|c|}{ 2"-O-rhamnopyranosyl } \\
\hline $\mathbf{1}^{\prime \prime \prime}$ & 101.03 & $5.21(\mathrm{~d}, 1.5)$ & $4^{\prime \prime \prime}$ & 71.97 & $3.18(t, 9.8)$ \\
\hline $2^{\prime \prime \prime}$ & 70.20 & $3.85^{\dagger}$ & $5^{\prime \prime \prime}$ & 68.89 & $3.64(\mathrm{dd}, 9.5,6.1)$ \\
\hline $3^{\prime \prime \prime}$ & 70.20 & $3.37(\mathrm{~m})$ & $6^{\prime \prime \prime}$ & 17.78 & $1.04(\mathrm{~d}, 6.1)$ \\
\hline \multicolumn{6}{|c|}{ 3"-O-glucopyranosyl } \\
\hline $1^{\prime \prime \prime \prime \prime}$ & 103.01 & $4.42(\mathrm{~d}, 7.6)$ & $4^{\prime \prime \prime \prime}$ & 69.93 & $3.13(t, 9.8)$ \\
\hline $2^{\prime \prime \prime \prime}$ & 73.33 & $3.13(t, 9.8)$ & $5^{\prime \prime \prime \prime}$ & 72.91 & $3.85^{\dagger}$ \\
\hline $3^{\prime \prime \prime \prime}$ & 76.53 & $3.22(t, 9.2)$ & $6^{\prime \prime \prime \prime}$ & 62.89 & $\begin{array}{l}4.10 \text { (dd, 11.9, 6.7), } \\
4.32 \text { (brd, 9.8) }\end{array}$ \\
\hline
\end{tabular}

* The ${ }^{13} \mathrm{C}$ - and ${ }^{1} \mathrm{H}$ - assignments were based on 2D NMR experiments (DQF-COSY, HMQC and $\mathrm{HMBC}$ ); ${ }^{\dagger}$ Signal patterns are unclear due to overlapping; $\mathrm{s}=$ singlet, $\mathrm{d}=$ doublet, $\mathrm{dd}=$ doublet of doublets, $\mathrm{t}=$ triplet, $\mathrm{m}=$ multiplet, brd = broad doublet, $\mathrm{ddd}=$ triplet of doublets.

On the other hand, the presence of three proton signals represented by three doublets at $\delta_{\mathrm{H}} 4.42(\mathrm{~J}$ = $7.6 \mathrm{~Hz}), 5.21(J=1.5 \mathrm{~Hz})$ and $5.49(J=7.3 \mathrm{~Hz})$, characteristic for the anomeric protons of two $\beta$ glucoyranosyl and one $\alpha$-rhamnopyranosyl moieties indicated its triglycosidic structure. The secondary-methyl signal at $\delta_{\mathrm{H}} 1.04(\mathrm{~d}, J=6.1 \mathrm{~Hz})$ supported the presence of a rhamnose unit. The sugar moiety was further confirmed by the DEPT spectrum, which revealed the presence of $18 \mathrm{C}$ signals, of which three at $\delta_{\mathrm{C}} 97.27,101.03$, and 103.01 represent anomeric carbon signals, 12 methine carbon signals, two oxymethylene carbons at $\delta_{\mathrm{C}} 60.89$ and 62.89 , and one methyl carbon at $\delta_{\mathrm{C}} 17.78$. The downfield shift of the C-2 signal at $\delta_{\mathrm{C}} 82.3$ of glucopyranosyl-I in the ${ }^{13} \mathrm{C}-\mathrm{NMR}$ of the glucosides was typical of an atom that has undergone a rhamnopyranosyl glycosidation and the downfield C-3 at $\delta_{\mathrm{C}} 83.5$ corresponds to the glycosidation of glucopyranosyl-II. The absence of any ${ }^{13} \mathrm{C}-\mathrm{NMR}$ 
glycosidation shift for the rhamnopyranosyl and the second glucopyranosyl residues suggested that these sugars are terminal. The inter-glycosidic linkages were confirmed by the HMBC correlations observed between the following protons and carbons: $\mathrm{H}-1^{\prime \prime \prime}$ of the rhamnose $\left(\delta_{\mathrm{H}} 5.21 \mathrm{~d}\right)$ and C-2" of the central glucose $\left(\delta_{\mathrm{C}} 76.53\right)$, and $\mathrm{H}-1^{\prime \prime \prime \prime}$ of the terminal glucose $\left(\delta_{\mathrm{H}} 4.42 \mathrm{~d}\right)$ and $\mathrm{C}-3^{\prime \prime}$ of the central glucose $\delta_{\mathrm{C}} 86.63$ (Figure 2). The presence of two carbon signals at $\delta_{\mathrm{C}} 20.38\left(\mathrm{CH}_{3}\right)$ and $170.04(\mathrm{CO})$ as well as a sharp singlet in the ${ }^{1} \mathrm{H}-\mathrm{NMR}$ spectrum at $\delta_{\mathrm{H}} 1.94(\mathrm{~s}, 3 \mathrm{H})$ indicated the presence of an acetyl group. Downfield shifts of $\mathrm{H}_{2}-6^{\prime \prime \prime \prime}\left(\delta_{\mathrm{H}} 4.10 \mathrm{dd}\right.$ and $4.32 \mathrm{~d}$ ) and an upfield shift of C-5'"'" $\left(\delta_{\mathrm{C}} 72.91\right)$ signals indicated the bonding site of the acetyl function. Additionally, HMBC correlations between the acetyl carbonyl group $\delta_{\mathrm{C}} 170.04$ and 2 protons of C-6"'"' showed that the acetyl group was located at C$6^{\prime \prime \prime \prime}$ of the terminal glucose. The attachment of the sugar moiety to the aglycone was determined from the long-range correlation between $\mathrm{H}-1^{\prime \prime}$ of the inner glucose $\left(\delta_{\mathrm{H}} 5.49 \mathrm{~d}\right)$ and $\mathrm{C}-7$ of the aglycone $\delta_{\mathrm{C}}$ 150.87. The HMBC connectivities are shown in Figure 2. ${ }^{1} \mathrm{H}$ - and ${ }^{13} \mathrm{C}-\mathrm{NMR}$ spectral data of each sugar unit and the deshielding effect of the connections were further confirmed by a comparison of its spectral data with literature values for flavonoid triglycosides [17-19]. From all these results, KSR1 was identified as 3'-(3R-acetoxy-5,5-dimethylcyclopent-1-ene)-4'-O-methylscutellarein 7-O-(6"''-Oacetyl- $\beta$-D-glucopyranosyl-( $1 \rightarrow 3)$-[ $\alpha$-L-rhamnopyranosyl- $(1 \rightarrow 2)]-\beta$-D-glucopyranoside. To the best of our knowledge this represents the first time that this compound has been isolated from natural sources and the trivial name saussureanoid is proposed.

Figure 2. Significant HMBC correlations for KSR1. Arrows point from H to C.

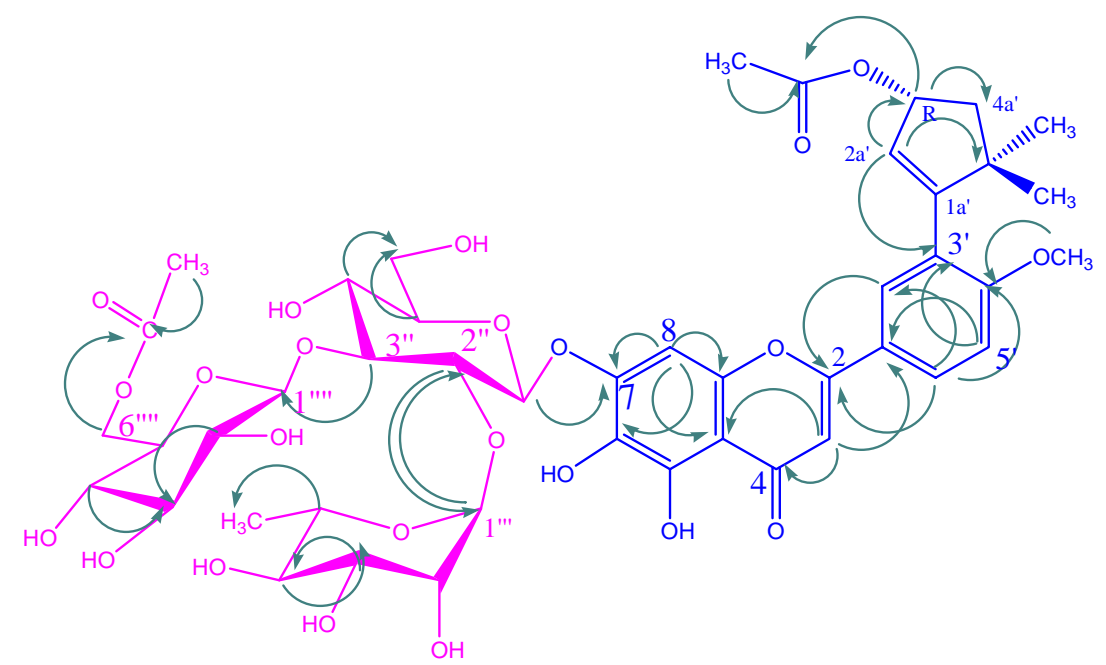

KSR2

KSR2 was obtained as a white amorphous powder, with negative optical rotation $\left[[\alpha]_{D}{ }^{21}-31.1^{\circ}\right.$, c $\left.=0.48 ; \mathrm{MeOH}-\mathrm{H}_{2} \mathrm{O}(1: 1)\right]$. The HR-FAB-MS of KSR2 exhibited a pseudo molecular ion $[\mathrm{M}+1]^{+}$at $\mathrm{m} / \mathrm{z}$ 1269.39, compatible with the molecular formula $\mathrm{C}_{53} \mathrm{H}_{72} \mathrm{O}_{35}$ (calc.1268.12). This was in good agreement with the presence of three methyl, four methylene, 36 methine and 10 quaternary carbon resonances in its ${ }^{13} \mathrm{C}-\mathrm{NMR}$ and DEPT spectra (Table 2). Positive results of the HCl-Mg reaction and the Molisch reaction indicated it to be a flavonoid glycoside. Its UV spectrum showed $\lambda_{\max }$ at 378,344 , 300 and $210 \mathrm{~nm}$, indicating its polyphenolic nature and addition to this in methanol it showed an absorptions at 262 (band II) and 346 (band I) nm. The bathochromic shift (48 nm) of band I with aluminium chloride- $\mathrm{HCl}$ and bathochromic shift $(6 \mathrm{~nm})$ of band II with sodium acetate indicted KSR2 
was a 5-hydroxy-3-O-substituted flavonol with the possible presence of two free hydroxy groups at C7 and C-4' [20]. The FABMS spectrum of KSR2 gave peaks at m/z [286+Na] (aglycone), [257+Na] (aglycone-CO-H) suggesting that the aglycone was kaempferol, which was confirmed by the presence characteristic signals of the kaempferol nucleus [21-22]; in the ${ }^{1} \mathrm{H}-\mathrm{NMR}$ spectrum, two doublets at $\delta_{\mathrm{H}}$ 6.20 and $6.40(\mathrm{~J}=2.1 \mathrm{~Hz})$ were assigned to the $\mathrm{H}-6$ and $\mathrm{H}-8$ protons respectively, and a pair of $\mathrm{A}_{2} \mathrm{~B}_{2}$ aromatic system protons at $\delta_{\mathrm{H}} 6.93$ and $7.77\left(\mathrm{~J}=8.4 \mathrm{~Hz}\right.$ ) were assigned to $\mathrm{H}-3^{\prime}, \mathrm{H}-5^{\prime}$ and $\mathrm{H}-2^{\prime}, \mathrm{H}-6^{\prime}$, respectively (Table 2). A series of peaks are seen in the ${ }^{1} \mathrm{H}$-NMR that are a duplicate of those assigned to the glycosidic part attached at C-7 in KSR1 [23] and a cross peak is observed in the HMBC (Figure $3)$ for $\mathrm{C}-7$ and $\mathrm{C}-1^{\prime \prime}$. From these we concluded that the same trisaccharide chain $-O-\left(6^{\prime \prime \prime \prime}-O\right.$-acetyl- $\beta$ $D$-glucopyranosyl-( $(\rightarrow 3)$-[ $\alpha$-L-rhamnopyranosyl- $(1 \rightarrow 2)]-\beta$ - $D$-glucopyranoside is attached at the C-7 position in KSR2. This was also confirmed by its hydrolysis (cf. Figure 1). KSR2 was proven to be a C-3 substituted monodesmosidic flavonol glycoside by comparing its ${ }^{1} \mathrm{H}-\mathrm{NMR}$ and ${ }^{13} \mathrm{C}-\mathrm{NMR}$ spectra with literature values. The presence of three proton signals represented by $\delta_{\mathrm{H}} 5.30(\mathrm{~d}, J=7.7 \mathrm{~Hz}$ ), 4.42 (s) and $4.34\left(\mathrm{~d}, J=7.8 \mathrm{~Hz}\right.$ ) indicated its triglycosidic structure. The secondary-methyl signal at $\delta_{\mathrm{H}} 1.16$ (s) supported the presence of a rhamnose unit. Presence of $18 \mathrm{C}$ signals and three anomeric carbon signals at $\delta_{C}$ 102.3, 100.03, 104.6 [24]. The data is shown in Table 3. From the HMBC experiment correlations were found between the rhamnopyranosyl methyl protons $\left(\delta_{\mathrm{H}} 1.16\right.$, s) and two carbon atoms $\delta_{\mathrm{C}} 82.3$, 66.8 assignable to the C-4a" and C-5a" of the rhamnose (Figure 3).

Figure 3. Significant HMBC Correlations for KSR2. Arrows point from H to C.

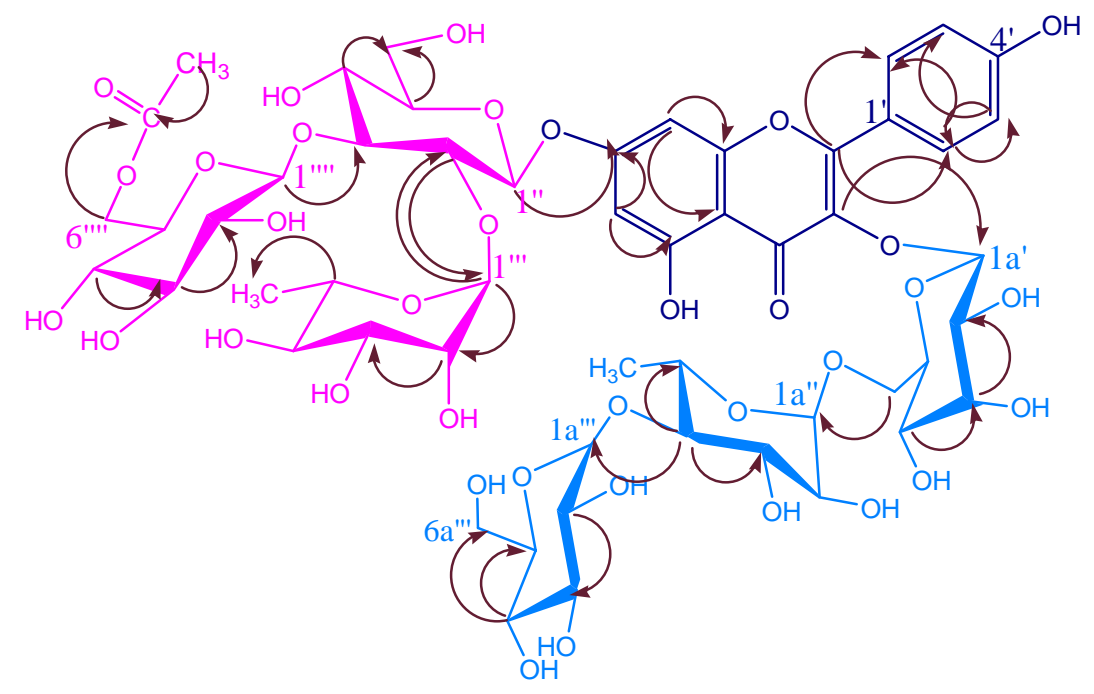

The downfield C-4a" signal at $\delta_{\mathrm{C}} 82.3$ was typical of an atom that has undergone a glycosidation. In HMBC correlations cross peaks were found between the rhamnopyranosyl anomeric proton $\delta_{\mathrm{H}} 4.42$ and the methylene carbon $\delta_{\mathrm{C}} 65.4$ assignable to the C-6a' of the galactose, and between C- $4 \mathrm{a}^{\prime \prime}$ of the rhamnose and the anomeric proton $\delta_{\mathrm{H}} 4.34(\mathrm{~d}, J=7.8 \mathrm{~Hz})$ of the glucose residue. Corresponding carbon signals $\delta_{\mathrm{C}}$ C-1a"' 104.6, C-2a"' 74.6, C-3a"' 76.7, C-4a"' 70.2, C-5a"' 77.0 and C-6a"' 61.3 (Table 3) together with proton signals of the same spin system given by the TOCSY spectrum, proved the existence of a terminal glucopyranosyl unit. The remaining six carbon signals of the saccharide part, together with proton signals of the same spin system given by TOCSY spectrum, were in good agreement with a galactopyranosyl unit with C-6a' substituted by a rhamnopyranosyl unit. Glycosidation shifts of the rhamnopyranosyl C-4a" $\delta_{\mathrm{C}} 82.3$, C-3a" $\delta_{\mathrm{C}} 70.0$, and C-5a" $\delta_{\mathrm{C}} 66.8$ (Table 
3) were observed by comparing with the ${ }^{13} \mathrm{C}-\mathrm{NMR}$ data of kaempferol 3-O- $\alpha$-L-rhamnopyranosyl$(1 \rightarrow 6)-\beta$-D-galactopyranoside [24-27]. The long range HMBC correlations are shown in Figure 3. As a result, we concluded that KSR2 could be unambiguously identified as kaempferol-3-O- $\beta$ - $D$ -

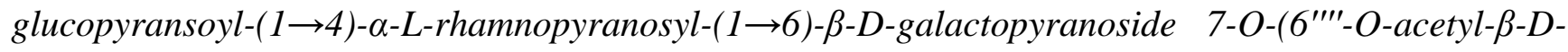
glucopyranosyl- $(1 \rightarrow 3)$-[ $\alpha$-L-rhamnopyranosyl- $(1 \rightarrow 2)]-\beta$-D-glucopyranoside.

Table 2. ${ }^{13} \mathrm{C}-(125 \mathrm{MHz})$ and ${ }^{1} \mathrm{H}-\mathrm{NMR}(500 \mathrm{MHz})$ spectral data for the aglycone and trisaccharide moieties attached at the C-7 position in KSR2, 3 and $4 *\left(\mathrm{D}_{2} \mathrm{O}\right)$

\begin{tabular}{|c|c|c|c|c|c|c|}
\hline \multirow{2}{*}{$\mathbf{C} / \mathbf{H}$} & \multicolumn{2}{|r|}{ KSR2 } & \multicolumn{2}{|r|}{ KSR3 } & \multicolumn{2}{|r|}{ KSR4 } \\
\hline & $\boldsymbol{\delta}_{\mathrm{C}}$ & $\delta_{H}(m, J)$ & $\boldsymbol{\delta}_{\mathrm{C}}$ & $\delta_{H}(m, J)$ & $\boldsymbol{\delta}_{\mathrm{C}}$ & $\delta_{H}(m, J)$ \\
\hline \multicolumn{7}{|c|}{ Aglycone } \\
\hline 2 & 156.7 & & 156.5 & & 156.7 & \\
\hline 3 & 133.5 & & 133.1 & & 133.5 & \\
\hline 4 & 177.5 & & 177.3 & & 177.5 & \\
\hline $4 a$ & 104.0 & & 104.1 & & 104.0 & \\
\hline 5 & 161.3 & & 161.2 & & 161.3 & \\
\hline 6 & 99.0 & $6.20(\mathrm{~s})$ & 98.8. & $6.22(\mathrm{~s})$ & 99.0 & $6.20(\mathrm{~s})$ \\
\hline 7 & 164.6 & & 164.1 & & 164.6 & \\
\hline 8 & 93.9 & $6.42(\mathrm{~s})$ & 93.7 & $6.41(\mathrm{~s})$ & 93.9 & $6.42(\mathrm{~s})$ \\
\hline $8 a$ & 156.6 & & 156.3 & & 156.6 & \\
\hline $\mathbf{1}^{\prime}$ & 121.0 & & 121.6 & & 121.0 & \\
\hline $2^{\prime}$ & 131.1 & $8.05(\mathrm{~d}, 8.6)$ & 131.1 & $8.04(\mathrm{~d}, 8.6)$ & 131.1 & $8.05(\mathrm{~d}, 8.6)$ \\
\hline $3^{\prime}$ & 115.2 & $6.87(\mathrm{~d}, 8.6)$ & 115.2 & $6.9(\mathrm{~d}, 8.6)$ & 115.2 & $6.87(d, 8.6)$ \\
\hline $4^{\prime}$ & 160.1 & & 160.3 & & 160.1 & \\
\hline $5^{\prime}$ & 115.2 & $6.87(\mathrm{~d}, 8.6)$ & 115.3 & $6.9(\mathrm{~d}, 8.6)$ & 115.2 & $6.87(\mathrm{~d}, 8.6)$ \\
\hline $6^{\prime}$ & 131.1 & $8.05(\mathrm{~d}, 8.6)$ & 131.2 & $8.04(\mathrm{~d}, 8.6)$ & 131.1 & $8.05(\mathrm{~d}, 8.6)$ \\
\hline \multicolumn{7}{|c|}{ 7-O-glucopyranosyl } \\
\hline 1" & 97.27 & $5.49(\mathrm{~d}, 7.3)$ & 98.20 & $5.46(d, 7.3)$ & 97.30 & $5.49(\mathrm{~d}, 7.3)$ \\
\hline $2^{\prime \prime}$ & 76.53 & $3.81(\mathrm{~d}, 9.4)$ & 76.55 & $3.84(\mathrm{~d}, 9.4)$ & 76.50 & $3.87(d, 9.4)$ \\
\hline $3 "$ & 86.63 & $3.73(t, 9.4)$ & 86.62 & $3.72(t, 9.4)$ & 86.77 & $3.76(t, 9.4)$ \\
\hline $4^{\prime \prime}$ & 68.14 & $4.08(\mathrm{dd}, 3.3,1.8)$ & 68.15 & $4.68(\mathrm{dd}, 3.3,1.8)$ & 68.14 & 4.07 (dd, 3.3, 1.8) \\
\hline $5 "$ & 76.85 & $3.25(t, 9.8)$ & 76.85 & $3.52(t, 9.8)$ & 76.88 & $3.30(t, 9.8)$ \\
\hline 6" & 60.89 & $3.44(\mathrm{dd}, 12.0,6.0)$ & 60.89 & $3.46(\mathrm{dd}, 12.0,6.0)$ & 60.86 & $\begin{array}{l}3.43(\mathrm{dd}, 12.0, \\
6.0)\end{array}$ \\
\hline $\mathrm{OCOCH}_{3}$ & 20.38 & $1.94(\mathrm{~s})$ & 20.38 & $1.95(\mathrm{~s})$ & 20.50 & $2.00(\mathrm{~s})$ \\
\hline $\mathrm{OC}_{\underline{C C H}}$ & 170.04 & & 170.50 & & 170.60 & \\
\hline \multicolumn{7}{|c|}{ 2"-O-rhamnopyranosyl } \\
\hline $1^{\prime \prime \prime}$ & 101.03 & $5.21(\mathrm{~d}, 1.5)$ & 101.01 & $5.20(\mathrm{~d}, 1.5)$ & 101.00 & $5.25(d, 1.5)$ \\
\hline $2^{\prime \prime \prime}$ & 70.20 & $3.85^{\dagger}$ & 70.24 & $3.85^{\dagger}$ & 70.20 & $3.85^{\dagger}$ \\
\hline $3^{\prime \prime \prime}$ & 70.20 & 3.37 (m) & 70.20 & $3.37(\mathrm{~m})$ & 70.20 & $3.38(\mathrm{~m})$ \\
\hline $4^{\prime \prime \prime}$ & 71.97 & $3.18(t, 9.8)$ & 71.99 & $3.20(t, 9.8)$ & 72.03 & $3.19(t, 9.8)$ \\
\hline $5^{\prime \prime \prime}$ & 68.89 & 3.64 (dd, 9.5, 6.1) & 68.88 & $3.60(\mathrm{dd}, 9.5,6.1)$ & 68.89 & 3.64 (dd, 9.5, 6.1) \\
\hline $6^{\prime \prime \prime}$ & 17.78 & $1.04(\mathrm{~d}, 6.1)$ & 17.80 & $1.06(\mathrm{~d}, 6.1)$ & 17.77 & $1.05(\mathrm{~d}, 6.1)$ \\
\hline
\end{tabular}


Table 2. Cont.

\begin{tabular}{|l|r|l|r|l|r|l|}
\hline \multicolumn{7}{|c|}{ 3"-O-glucopyranosyl } \\
\hline $\mathbf{1}^{\prime \prime \prime \prime \prime}$ & 103.01 & $4.42(\mathrm{~d}, 7.6)$ & 103.05 & $4.46(\mathrm{~d}, 7.6)$ & 103.04 & $4.45(\mathrm{~d}, 7.6)$ \\
$\mathbf{2}^{\prime \prime \prime \prime \prime}$ & 73.33 & $3.13(\mathrm{t}, 9.8)$ & 73.33 & $3.15(\mathrm{t}, 9.8)$ & 73.35 & $3.17(\mathrm{t}, 9.8)$ \\
$\mathbf{3}^{\prime \prime \prime \prime \prime}$ & 76.53 & $3.24(\mathrm{t}, 9.2)$ & 76.53 & $3.22(\mathrm{t}, 9.2)$ & 76.57 & $3.26(\mathrm{t}, 9.2)$ \\
$\mathbf{4}^{\prime \prime \prime \prime \prime}$ & 69.93 & $3.16(\mathrm{t}, 9.8)$ & 69.93 & $3.14(\mathrm{t}, 9.8)$ & 69.90 & $3.13(\mathrm{t}, 9.8)$ \\
$\mathbf{5}^{\prime \prime \prime \prime \prime}$ & 72.91 & $3.85(\mathrm{~m})$ & 72.96 & $3.89(\mathrm{~m})$ & 72.98 & $3.88(\mathrm{~m})$ \\
$\mathbf{6}^{\prime \prime \prime \prime \prime}$ & 62.89 & $4.15(\mathrm{dd}, 11.9$, & 62.89 & $4.10(\mathrm{dd}, 11.9$, & 62.86 & $4.10(\mathrm{dd}, 11.9$, \\
& & $6.7)$ & & $6.7)$ & & $6.7)$ \\
& & $4.35(\mathrm{brd}, 9.8)$ & & 4.36 (brd, 9.8) & & 4.38 (brd, 9.8) \\
\hline
\end{tabular}

* The ${ }^{13} \mathrm{C}$ - and ${ }^{1} \mathrm{H}$ - assignments were based on 2D NMR (DQF-COSY, HMQC and HMBC) experiments; ${ }^{\dagger}$ Signal patterns are unclear due to overlapping; $\mathrm{s}=$ singlet, $\mathrm{d}=$ doublet, $\mathrm{dd}=$ doublet of doublet, $\mathrm{t}=$ triplet, $\mathrm{m}=$ multiplet, brd = broad doublet, ddd $=$ triplet of doublets .

KSR3

KSR3 was obtained as a white amorphous powder, with negative optical rotation $\left[[\alpha]_{\mathrm{D}}{ }^{21}-31.1^{\circ}, \mathrm{c}=\right.$ 0.48; $\left.\mathrm{MeOH}-\mathrm{H}_{2} \mathrm{O}(1: 1)\right]$. Its HR-FAB-MS exhibited a pseudo molecular ion $[\mathrm{M}+1]^{+}$at $\mathrm{m} / \mathrm{z} 1285.38$ compatible with the molecular formula $\mathrm{C}_{56} \mathrm{H}_{68} \mathrm{O}_{34}$ (calc. 1284.12). This was in good agreement with the presence of two methyl, four methylene, 37 methine and 13 quaternary carbon resonances in its ${ }^{13} \mathrm{C}-\mathrm{NMR}$ spectra (Table 2). Positive results of the $\mathrm{HCl}-\mathrm{Mg}$ reaction and the Molisch reaction indicated it to be a flavonoid glycoside. Its UV spectrum showed $\lambda_{\max }$ at 378, 344, 300 and $210 \mathrm{~nm}$, indicating its polyphenolic nature. In the ${ }^{1} \mathrm{H}-\mathrm{NMR}$ of KSR3 a set of signals identical to those of the parent nucleus of KSR2 was found, as shown in Table 2. In addition to this there are two $\beta$-glucopyranosyl units from the anomeric signals at $\delta_{\mathrm{C}} 101.5$ and 105.6 as well as the other signals characteristic for glucopyransoyl units as shown in Table 3 [28]. From ${ }^{1} \mathrm{H}$-NMR spectral data of KSR3 the $\delta_{\mathrm{H}} 5.11$ (d, $J$ $=7.6 \mathrm{~Hz}$ ) of the anomeric proton one of the two glucopyranosyl units indicated its $\beta$ configuration. Moreover, the coupling constant $\left(15.6 \mathrm{~Hz}\right.$ ) of the two doublets at $\delta_{\mathrm{H}} 5.59$ and 7.30 (each $1 \mathrm{H}$ ) indicated the trans configuration of the caffeoyl moiety (fission) in the ${ }^{13} \mathrm{C}-\mathrm{NMR}$ spectrum of compound 3 the downfield shift of C-2a" $\delta_{C} 82.2$ together with the upfield shift of C-1a" $\delta_{C} 101.5$ (Table 3) proved the attachment of the terminal glucosyl unit to this position [29]. Furthermore, the signal at $\delta_{\mathrm{C}} 64.6$ was assigned to the C-6a' or C-6a" in these two glucosyl units to which the caffeoyl moiety is attached [30] this can be determine the attachment site of the caffeoyl moiety little amount of the KSR3 was acetylated and subjected to EI-MS spectral analysis according to the procedure established in reference [31] which revealed a characteristic peak at $\mathrm{m} / \mathrm{z} 331$ (18\%) corresponding to tetraacetylated glucose as a cationic fragment with a molecular formula $\left[\mathrm{C}_{14} \mathrm{H}_{19} \mathrm{O}_{9}\right]^{+}$as shown in Figure 4. This significant peak proved the presence of an unsubstituted terminal glucosyl unit [31]. Consequently, the attachment site of the caffeoyl moiety must be at C-6a' of the glucopyranosyl. The connectivity is shown in Figure 5, as also conformed by HMBC and consequently KSR3 was identified as kaempferol-3-O- $\beta$ - $D$ glucopyranosyl $(1 \rightarrow 2)-\beta$-D-(6a'-O-caffeoyl)-glucopyranoside $\quad 7-O-\left(6^{\prime \prime \prime}-\right.$-O-acetyl- $\beta$-D-glucopyranosyl$(1 \rightarrow 3)$-[ $\alpha$-L-rhamno-pyranosyl- $(1 \rightarrow 2)]-\beta$-D-glucopyranoside. 
Figure 4. EI-MS fragmentation of KSR3.

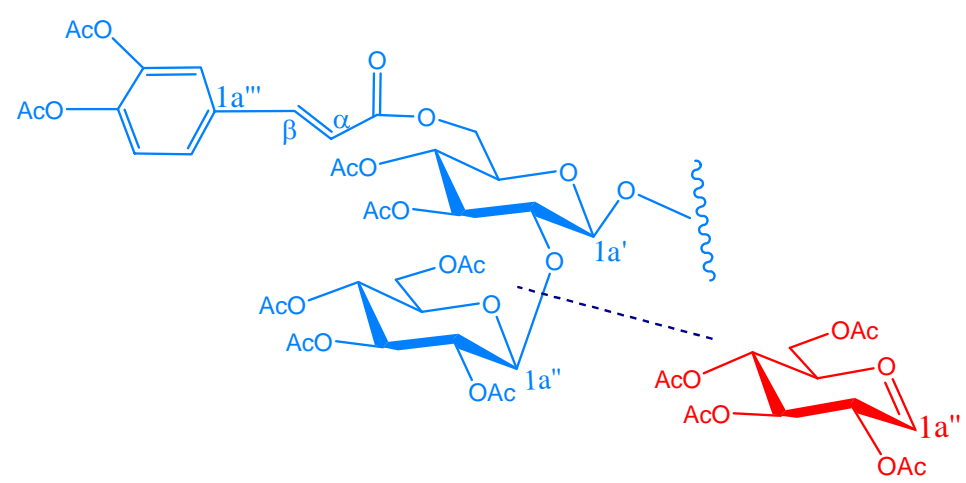

Figure 5. Significant HMBC correlations of KSR3. Arrows point from $\mathrm{H}$ to C.

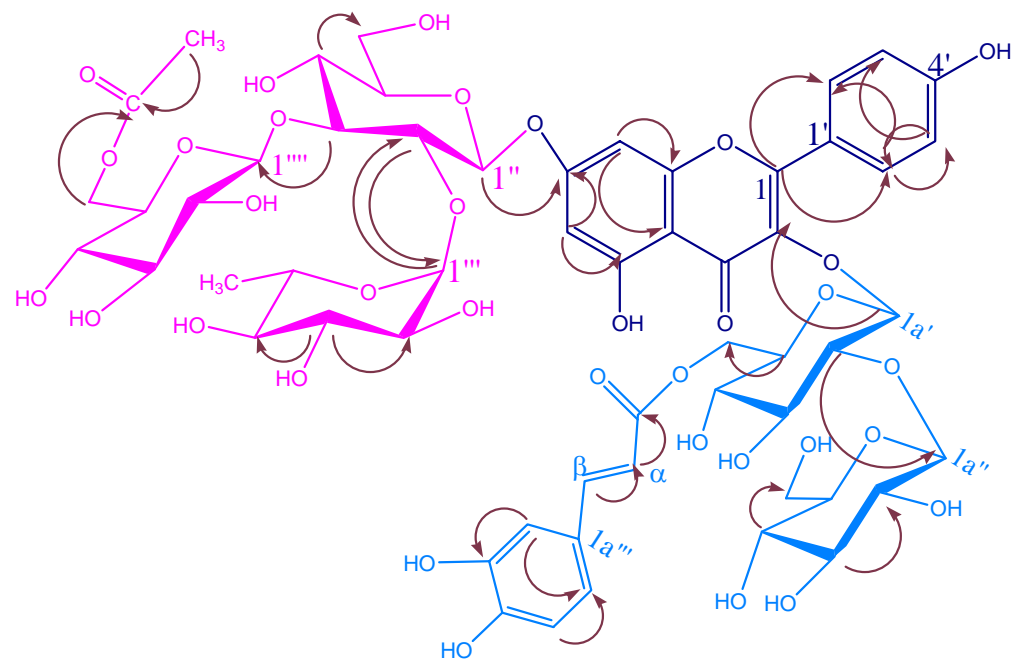

Table 3. ${ }^{13} \mathrm{C}$ - and ${ }^{1} \mathrm{H}$-NMR spectral data for side groups attached at the $\mathrm{C}-3$ position in compounds KSR2, KSR3 and KSR4 * $\left(\mathrm{D}_{2} \mathrm{O},{ }^{13} \mathrm{C}: 125 \mathrm{MHz} ;{ }^{1} \mathrm{H}: 500 \mathrm{MHz}\right)$.

\begin{tabular}{|c|c|c|c|c|c|}
\hline \multicolumn{6}{|c|}{ KSR2 } \\
\hline $\mathbf{C} / \mathbf{H}$ & $\boldsymbol{\delta}_{\mathrm{C}}$ & $\delta_{H}(\mathbf{m}, \mathbf{J} \mathbf{H z})$ & $\mathbf{C} / \mathbf{H}$ & $\boldsymbol{\delta}_{\mathrm{C}}$ & $\delta_{\mathbf{H}}(\mathbf{m}, \mathbf{J} \mathbf{H z})$ \\
\hline \multicolumn{6}{|c|}{ 3-O-galactopyranosyl } \\
\hline $1 a^{\prime}$ & 102.3 & $5.30(\mathrm{~d}, 7.7)$ & $4 a^{\prime}$ & 68.1 & $3.83(\mathrm{dm}, 3.3)$ \\
\hline $2 \mathbf{a}^{\prime}$ & 71.2 & 3.57 (dd, 9.8,7.4) & $5 a^{\prime}$ & 73.6 & 3.47 (ddm, 7.5, 5) \\
\hline $3 \mathbf{a}^{\prime}$ & 73.1 & 3.51 (dd, 9.8, 3.3) & $6 \mathbf{a}^{\prime}$ & 65.4 & 3.23 (dd, 11.7, 7.5) \\
\hline & & & & & $3.62(\mathrm{dd}, 11.7,5)$ \\
\hline \multicolumn{6}{|c|}{ 4a"-O-glucopyranosyl } \\
\hline $1 a^{\prime \prime \prime}$ & 104.6 & $4.34(\mathrm{~d}, 7.8)$ & $4 a^{\prime \prime \prime}$ & 70.2 & $3.02(\mathrm{~m})$ \\
\hline $2 a^{\prime \prime \prime}$ & 74.6 & 2.99 (dd, 9.8, 7.7) & $5 a^{\prime \prime \prime}$ & 77.0 & $3.55(\mathrm{~m})$ \\
\hline $3 a^{\prime \prime \prime}$ & 76.7 & 3.15 (dd, 8.7, 7.4) & $6 a^{\prime \prime \prime}$ & 61.3 & 3.44 (dd, 11.5, 5.2) \\
\hline & & & & & $3.67(\mathrm{~d}, 10.9)$ \\
\hline \multicolumn{6}{|c|}{ 6a'-O-rhamnopyranosyl } \\
\hline $1 a^{\prime \prime}$ & 100.0 & 4.42 (brd, 1.8) & $4 a^{\prime \prime}$ & 82.3 & $3.37(d, 9.5)$ \\
\hline $2 a^{\prime \prime}$ & 70.2 & 3.48 (dd, 3.3, 1.8) & $5 a^{\prime \prime}$ & 66.8 & 3.47 (dq, 9.5,6.2) \\
\hline $3 a^{\prime \prime}$ & 70.7 & 3.56 (dd, 9.5, 3.3) & $6 a^{\prime \prime}$ & 17.9 & $1.16(\mathrm{~s})$ \\
\hline
\end{tabular}


Table 3. Cont.

\begin{tabular}{|c|c|c|c|c|c|}
\hline \multicolumn{6}{|c|}{ KSR3 } \\
\hline $\mathbf{C} / \mathbf{H}$ & $\boldsymbol{\delta}_{\mathrm{C}}$ & $\delta_{\mathrm{H}}(\mathrm{m}, \mathrm{J} \mathrm{Hz})$ & $\mathbf{C} / \mathbf{H}$ & $\boldsymbol{\delta}_{\mathrm{C}}$ & $\delta_{\mathrm{H}}(\mathrm{m}, \mathrm{J} \mathrm{Hz})$ \\
\hline \multicolumn{6}{|c|}{ 3-O-glucopyranosyl } \\
\hline $1 a^{\prime}$ & 101.5 & $4.30(\mathrm{~d}, 7.5)$ & $4 a^{\prime}$ & 70.0 & $3.03(\mathrm{dm}, 3.9)$ \\
\hline $2 \mathbf{a}^{\prime}$ & 82.2 & 3.61 (dd, 8.9, 7.5) & $5 a^{\prime}$ & 75.8 & 3.55 (ddm, 8.7, 5.8) \\
\hline $3 \mathbf{a}^{\prime}$ & 75.7 & $3.15(8.6,3.5)$ & $6 \mathbf{a}^{\prime}$ & 64.6 & 3.44 (dd, 11.6, 7.5) \\
\hline & & & & & 3.67 (dd, 11.7, 5) \\
\hline \multicolumn{6}{|c|}{ 6a'-O-caffeoyl } \\
\hline$\alpha \mathbf{a}^{\prime \prime}$ & 114.5 & $5.59(\mathrm{~d}, 15.6)$ & $4 a^{\prime \prime}$ & 146.9 & \\
\hline $\boldsymbol{\beta} \mathbf{a}^{\prime \prime}$ & 146.4 & $7.30(\mathrm{~d}, 15.6)$ & $5 a^{\prime \prime}$ & 116.3 & $6.62(\mathrm{~d}, 8.1)$ \\
\hline $1 a^{\prime \prime}$ & 127.4 & & 6a" & 122.8 & $6.69(\mathrm{~d}, 8.1)$ \\
\hline $2 a^{\prime \prime}$ & 115.0 & 6.79 (bs) & $\mathrm{COO}$ & 169.1 & \\
\hline $3 a^{\prime \prime}$ & 149.3 & $6.75(\mathrm{~d}, 8.7)$ & & & \\
\hline \multicolumn{6}{|c|}{ 2a'-O-glucopyranosyl } \\
\hline $1 a^{\prime \prime}$ & 105.6 & $4.81(\mathrm{~d}, 7.8)$ & $4 a^{\prime \prime}$ & 71.7 & $3.53(\mathrm{~d}, 8.9)$ \\
\hline $2 a^{\prime \prime}$ & 74.7 & 3.19 (dd, 8.1,3.3) & $5 a^{\prime \prime}$ & 77.7 & $3.23(\mathrm{~m})$ \\
\hline $3 a^{\prime \prime}$ & 76.7 & 3.38 (dd, 8.9,3.4) & $6 a^{\prime \prime}$ & 61.7 & $3.78(\mathrm{~m})$ \\
\hline & & & & & $3.80(\mathrm{~m})$ \\
\hline \multicolumn{6}{|c|}{ KSR4 } \\
\hline $\mathbf{C} / \mathbf{H}$ & $\boldsymbol{\delta}_{\mathrm{C}}$ & $\delta_{\mathbf{H}}(\mathbf{m}, \mathbf{J} \mathbf{H z})$ & $\mathbf{C} / \mathbf{H}$ & $\boldsymbol{\delta}_{\mathrm{C}}$ & $\delta_{\mathbf{H}}(\mathbf{m}, \mathbf{J} \mathbf{H z})$ \\
\hline \multicolumn{6}{|c|}{ 3-O-rhamnopyranosyl } \\
\hline $1 a^{\prime}$ & 100.1 & $5.60(\mathrm{~d}, 1.7)$ & $4 a^{\prime}$ & 70.9 & $3.64(t, 9.7)$ \\
\hline $2 \mathbf{a}^{\prime}$ & 70.8 & $5.83(\mathrm{~d}, 1.7)$ & $5 a^{\prime}$ & 72.1 & $3.56(\mathrm{~m})$ \\
\hline $3 \mathbf{a}^{\prime}$ & 72.9 & $5.30(\mathrm{dd}, 9.7,3.4)$ & $6 a^{\prime}$ & 17.7 & $1.06(\mathrm{~d}, 6.3)$ \\
\hline \multicolumn{6}{|c|}{$2 a^{\prime}-O-E-p$-coumaroyl } \\
\hline$\alpha \mathbf{a}^{\prime \prime \prime}$ & 114.8 & $6.28(d, 15.9)$ & $4 a^{\prime \prime \prime}$ & 161.5 & \\
\hline$\beta a^{\prime \prime \prime}$ & 147.6 & $7.60(d, 15.9)$ & $5 a^{\prime \prime \prime}$ & 116.8 & $6.75(\mathrm{~d}, 8.7)$ \\
\hline $1 a^{\prime \prime \prime}$ & 127.0 & & $\mathbf{6 a}^{\prime \prime \prime}$ & 131.3 & $7.37(\mathrm{~d}, 8.4)$ \\
\hline $2 a^{\prime \prime \prime}$ & 131.3 & $7.37(\mathrm{~d}, 8.4)$ & COO & 168.4 & \\
\hline $3 a^{\prime \prime \prime}$ & 116.8 & & & & \\
\hline \multicolumn{6}{|c|}{ 3a'-O-E-p-coumaroyl } \\
\hline$\alpha a^{\prime \prime \prime}$ & 114.3 & $6.36(d, 15.9)$ & $4 a^{\prime \prime \prime}$ & 161.3 & \\
\hline$\beta a^{\prime \prime \prime}$ & 146.9 & $7.62(\mathrm{~d}, 15.9)$ & $5 a^{\prime \prime \prime}$ & 116.7 & $6.80(\mathrm{~d}, 8.7)$ \\
\hline $1 a^{\prime \prime \prime}$ & 126.9 & & $6 a^{\prime \prime \prime}$ & 131.1 & $7.44(\mathrm{~d}, 8.4)$ \\
\hline $2 a^{\prime \prime \prime}$ & 131.1 & $7.44(\mathrm{~d}, 8.4)$ & COO & 167.7 & \\
\hline $3 a^{\prime \prime \prime}$ & 116.7 & $6.80(\mathrm{~d}, 8.7)$ & & & \\
\hline
\end{tabular}

* The ${ }^{13} \mathrm{C}$ - and ${ }^{1} \mathrm{H}$ - assignments were based on 2D NMR (DQF-COSY, HMQC and HMBC) experiments; $\mathrm{s}=$ singlet, $\mathrm{d}=$ doublet, $\mathrm{dd}=$ doublet of doublet, $\mathrm{t}=$ triplet, $\mathrm{m}=$ multiplet, brd = broad doublet, ddd = triplet of doublets.

\section{KSR4}

KSR4 was obtained as a white amorphous powder, with negative optical rotation $\left[[\alpha]_{\mathrm{D}}{ }^{21}-32.1^{0}\right.$, c $\left.=0.45 ; \mathrm{MeOH}-\mathrm{H}_{2} \mathrm{O}(1: 1)\right]$. The HR-FAB-MS exhibited a pseudomolecular ion $[\mathrm{M}+1]^{+}$at $\mathrm{m} / \mathrm{z} 1237.38$ compatible with the molecular formula $\mathrm{C}_{59} \mathrm{H}_{64} \mathrm{O}_{29}$ (calc. 1236.12). This was in good agreement with 
the presence of 3 methyl, 2 methylene, 38 methine and 16 quaternary carbon resonances in its ${ }^{13} \mathrm{C}$ NMR spectra Table 2, Table 3. The characteristic UV spectrum of KSR4, a shoulder at $\lambda_{\max }=268 \mathrm{~nm}$ and a broad band at $\lambda_{\max }=312 \mathrm{~nm}$, suggested a diacylated glycoside [32]. The ${ }^{1} \mathrm{H}-\mathrm{NMR}$ spectrum displayed the typical signal pattern of KSR2 (Table 2) nucleus as in previous compounds, in addition to two p-coumaroyl moieties, as indicated by the presence of two pairs of doublets with a relatively large coupling constant $(15.9 \mathrm{~Hz})$ [33]. The first pair at $\delta_{\mathrm{H}} 6.63$ and 7.62 and the second at $\delta_{\mathrm{H}} 7.60$ and 6.36, indicated two pairs of trans configured ethylene protons. Additionally, two $\mathrm{A}_{2} \mathrm{~B}_{2}$ systems, each integrating for two protons, were found at $\delta_{\mathrm{H}} 7.44,6.80$ and $6.75,7.37$, respectively. This was also supported by a fragment at $\mathrm{M}^{+}[164+\mathrm{Na}]$ in HR-FAB-MS. It conform the presence of E-di-pcoumaroyl derivatives in the compound. ${ }^{1} \mathrm{H}$-NMR showed the presence of three downfield rhamnose proton signals at $\delta_{\mathrm{H}} 5.30(\mathrm{dd}, J=9.7,3.4 \mathrm{~Hz}), 5.60(\mathrm{~d}, J=1.7 \mathrm{~Hz})$ and $5.82(\mathrm{~d}, J=1.7 \mathrm{~Hz})$ which could be ascribed to H-3a', H-1a' and H-2a'. This assignment was deduced by the correlation of H-1a' with $\mathrm{H}-2 \mathrm{a}^{\prime}, \mathrm{H}-2 \mathrm{a}^{\prime}$ with $\mathrm{H}-1 \mathrm{a}^{\prime}$ and $\mathrm{H}-3 \mathrm{a}^{\prime}$, in ${ }^{1} \mathrm{H}-{ }^{1} \mathrm{H}$ COSY and cross peaks are also observed in HMBC between $\delta_{\mathrm{H}} 5.60 \mathrm{H}-1 \mathrm{a}^{\prime}$ of rhamnose and C-3 of kaempferol. The connectivity is showed in Figure 6 . The downfield shift of $\mathrm{H}-2 \mathrm{a}^{\prime}$ and $\mathrm{H}-3 \mathrm{a}^{\prime}$ of rhamnose, relative to the corresponding positions in literature proved their acylation by the two P-coumaric acid units. The acylation at C-2a' and C-3a' positions is further confirmed by the upfield shift of the adjacent carbons in ${ }^{13} \mathrm{C}$ of $\mathrm{C}-1 \mathrm{a}^{\prime}$ and $\mathrm{C}-4 \mathrm{a}^{\prime}$ relative to the corresponding carbons of kaempferol-3-O- $\alpha$-L-rhamnoside [34]. The assignments of the chemical shifts of the carbons were deduced by 2D NMR experiments (Table 3). Therefore, KSR4 was identified as kaempferol-3-O- $\alpha-L-\left(2 a^{\prime}, 3 a^{\prime}-E-d i-p\right.$-coumaroyl)-rhamnoside 7-O-(6"''-O-acetyl- $\beta$-Dglucopyranosyl-( $1 \rightarrow 3)-[\alpha$-L-rhamnopyranosyl-( $1 \rightarrow 2)]-\beta$-D-glucopyranoside.

Figure 6: Significant HMBC correlations for KSR4. Arrows point from H to C.

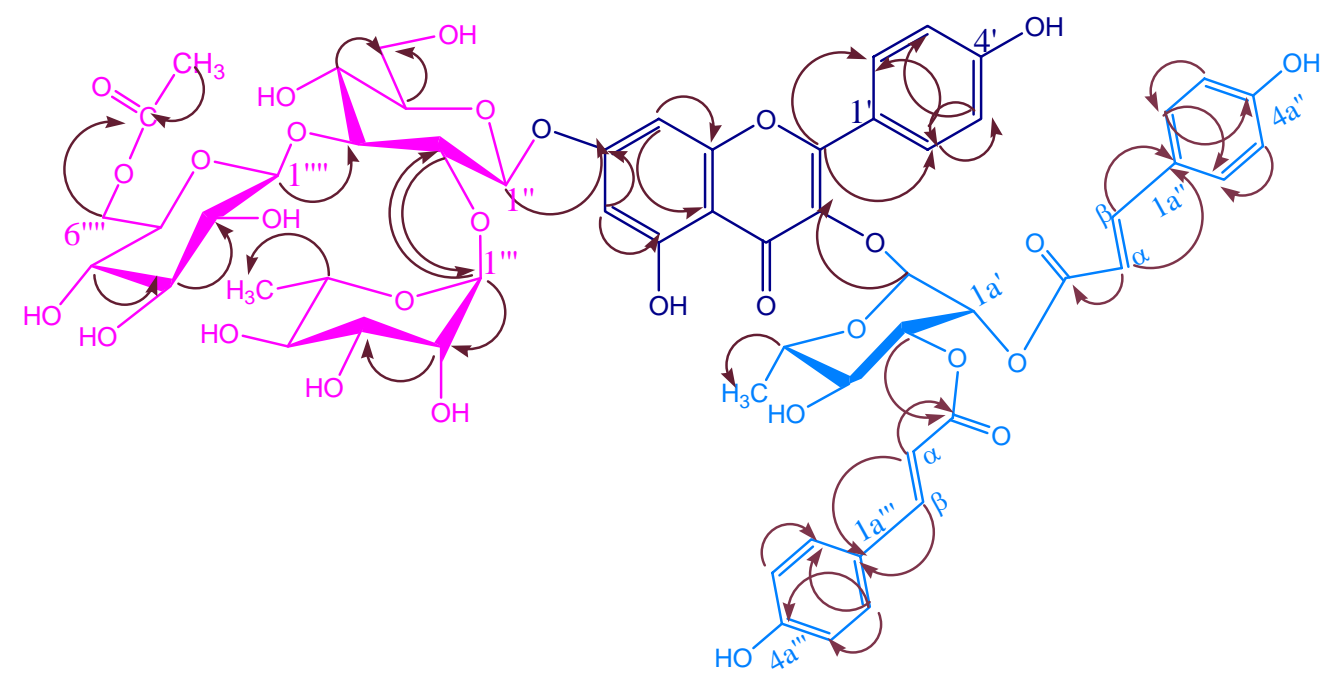

\section{Biological activity}

From Table 4, it can be seen that KSR4 possessed the highest antifungal potential, while KSR3 shows medium activity. Compounds KSR1 and KSR2, showed good activity, while the EtOH extract showed medium activity. The results of individual compounds are correlated with those obtained for the mixture of all four compounds. The mixture shows better activity than individual compounds. All 
the compounds and extracts tested show greater antifungal activity than miconazole, a commercial fungicide, which was used as a control. These results were obtained in duplicate or triplicate and the mean of the results taken. As for the antibacterial potential, only KSR4 and mixture of four compounds are active against all bacterial strains tested.

Table 4: Minimum inhibitory concentrations (MICs) and minimum fungicidal concentrations (MFCs), nmol/mL. MICs and MFCs are presented as mean values.

\begin{tabular}{|c|c|c|c|c|c|c|c|}
\hline Fungi & $\begin{array}{l}\text { EtOH } \\
\text { MIC } \\
\text { (MFC) }\end{array}$ & $\begin{array}{l}\text { KSR1 } \\
\text { MIC } \\
\text { (MFC) }\end{array}$ & $\begin{array}{l}\text { KSR2 } \\
\text { MIC } \\
\text { (MFC) }\end{array}$ & $\begin{array}{l}\text { KSR3 } \\
\text { MIC } \\
\text { (MFC) }\end{array}$ & $\begin{array}{l}\text { KSR4 } \\
\text { MIC } \\
\text { (MFC) }\end{array}$ & $\begin{array}{l}\text { R1 } \\
\text { MIC } \\
\text { (MFC) }\end{array}$ & $\begin{array}{l}\text { M1 } \\
\text { MIC } \\
\text { (MFC) }\end{array}$ \\
\hline A. niger & $\begin{array}{l}1.2 \\
(1.2)\end{array}$ & $\begin{array}{l}2.5 \\
(2.5)\end{array}$ & $\begin{array}{l}0.6 \\
(0.6)\end{array}$ & $\begin{array}{l}7.5 \\
(7.5)\end{array}$ & $\begin{array}{l}0.6 \\
(0.6)\end{array}$ & $\begin{array}{l}3.0 \\
(8.0)\end{array}$ & $\begin{array}{l}0.3 \\
(0.3)\end{array}$ \\
\hline A. ochraceus & $\begin{array}{l}1.2 \\
(1.2)\end{array}$ & $\begin{array}{l}2.5 \\
(2.5)\end{array}$ & $\begin{array}{l}0.6 \\
(0.6)\end{array}$ & $\begin{array}{l}7.5 \\
(7.5)\end{array}$ & $\begin{array}{l}0.6 \\
(0.6)\end{array}$ & $\begin{array}{l}3.0 \\
(8.0)\end{array}$ & $\begin{array}{l}0.3 \\
(0.3)\end{array}$ \\
\hline A. versicolor & $\begin{array}{l}0.6 \\
(1.2)\end{array}$ & $\begin{array}{l}2.5 \\
(2.5)\end{array}$ & $\begin{array}{l}0.3 \\
(0.6)\end{array}$ & $\begin{array}{l}7.5 \\
(7.5)\end{array}$ & $\begin{array}{l}0.6 \\
(1.2)\end{array}$ & $\begin{array}{l}4.0 \\
(8.0)\end{array}$ & $\begin{array}{l}0.3 \\
(0.3)\end{array}$ \\
\hline A. flavus & $\begin{array}{l}1.2 \\
(1.2)\end{array}$ & $\begin{array}{l}2.5 \\
(2.5)\end{array}$ & $\begin{array}{l}0.6 \\
(1.2)\end{array}$ & $\begin{array}{l}7.5 \\
(7.5)\end{array}$ & $\begin{array}{l}0.3 \\
(0.6)\end{array}$ & $\begin{array}{l}1.0 \\
(8.0)\end{array}$ & $\begin{array}{l}0.3 \\
(0.3)\end{array}$ \\
\hline P. ochrochloron & $\begin{array}{l}1.2 \\
(2.4)\end{array}$ & $\begin{array}{l}5.0 \\
(5.0)\end{array}$ & $\begin{array}{l}1.2 \\
(2.4)\end{array}$ & $\begin{array}{l}10.0 \\
(12.0)\end{array}$ & $\begin{array}{l}0.6 \\
(1.2)\end{array}$ & $\begin{array}{l}2.0 \\
(10.0)\end{array}$ & $\begin{array}{l}0.45 \\
(0.45)\end{array}$ \\
\hline P. funiculosum & $\begin{array}{l}1.2 \\
(2.4)\end{array}$ & $\begin{array}{l}1.25 \\
(1.25)\end{array}$ & $\begin{array}{l}1.2 \\
(2.4)\end{array}$ & $\begin{array}{l}10.0 \\
(12.0)\end{array}$ & $\begin{array}{l}0.6 \\
(1.2)\end{array}$ & $\begin{array}{l}4.0 \\
(10.0)\end{array}$ & $\begin{array}{l}0.45 \\
(0.45)\end{array}$ \\
\hline T. viride & $\begin{array}{l}1.2 \\
(2.4)\end{array}$ & $\begin{array}{l}5.0 \\
(7.5)\end{array}$ & $\begin{array}{l}1.2 \\
(1.2)\end{array}$ & $\begin{array}{l}10.0 \\
(15.0)\end{array}$ & $\begin{array}{l}1.2 \\
(2.4)\end{array}$ & $\begin{array}{l}4.0 \\
(4.0)\end{array}$ & $\begin{array}{l}0.45 \\
(0.45)\end{array}$ \\
\hline C. cladosporioides & $\begin{array}{l}3.45 \\
(3.75)\end{array}$ & $\begin{array}{l}2.4 \\
(2.4)\end{array}$ & $\begin{array}{l}12.0 \\
(10.0)\end{array}$ & $\begin{array}{l}8.0 \\
(4.0)\end{array}$ & $\begin{array}{l}5.0 \\
(5.0)\end{array}$ & $\begin{array}{l}0.06 \\
(0.06)\end{array}$ & $\begin{array}{l}1.25 \\
(1.25)\end{array}$ \\
\hline A. alternata & $\begin{array}{l}5.0 \\
(5.0)\end{array}$ & $\begin{array}{l}7.5 \\
(7.5)\end{array}$ & $\begin{array}{l}6.0 \\
(6.0)\end{array}$ & $\begin{array}{l}3.0 \\
(8.0)\end{array}$ & $\begin{array}{l}10.0 \\
(12.0)\end{array}$ & $\begin{array}{l}1.0 \\
(1.0)\end{array}$ & $\begin{array}{l}1.25 \\
(1.25)\end{array}$ \\
\hline
\end{tabular}

R1: miconazole; M1: Mixture of KSR1,2,3 and 4; all the tests were run in duplicate or triplicate.

\section{Acknowledgements}

Authors are thankful to RSIC, CDRI, Lucknow and IISC, Banglore, for spectral analysis. Thanks are due to Dr. P. Ramakrishna, IEMPS, Vikram University, Ujjain, for determining the biological activities. 


\section{Experimental}

\section{General}

${ }^{1} \mathrm{H}$ - and ${ }^{13} \mathrm{C}-\mathrm{NMR}$ spectra were recorded on a Varian Inova-500 instrument using the solvent peak ( $\delta 4.75$ or 3.31 for $\mathrm{D}_{2} \mathrm{O}-\mathrm{d}_{2}$ or DMSO- $\mathrm{d}_{6}$ respectively or the $\mathrm{CH}_{3}-1,2$ peak $\delta 61.5$ ) containing TMS as the internal standard. HSQC, HMBC, HMQC and NOESY spectra were recorded on a Bruker Avance-400 instrument. HR-FAB-MS (were recorded in positive model on a JEOL JMS-AX505W instrument using a bis(hydroxyethyl) disulfide matrix. Optical rotations were measured in $\mathrm{MeOH}$ with a Perkin-Elmer 241 Polarimeter. Column chromatography (CC) was carried out on Kieselgel 60 (63200 mesh) Merck, Fluka or Lichroprep RP-18 (40-63 $\mu \mathrm{m})$ Merck. HPLC was performed with a C-18 Dionex Vydac column (201SP510, 250×10 mm. 5 $\mu \mathrm{m})$ unsing a binary eluent [solvent $\mathrm{A} . \mathrm{H}_{2} \mathrm{O}(\mathrm{pH} 2.4$ with $0.025 \%$ TFA): solvent $\mathrm{B}$. MeCN] and a flow rate of $3 \mathrm{~mL} \mathrm{~min}^{-1}$.

\section{Plant Material:}

Saussurea lappa roots were obtained from the local market of Ujjain in October, 2003, and identified by Dr. P. Ramakrishna, IEMPS. A voucher sample is kept at the School of Studies in Chemistry of Vikram University. Dried and powered roots $(1 \mathrm{~kg})$ were macerated in $\mathrm{EtOH}$ for $17 \mathrm{~h}$ and then boiled for $3 \mathrm{~h}$. The extract was filtered, evaporated and freeze-dried to give a residue (106 g) which was suspended in EtOH $(400 \mathrm{~mL})$. The ethanolic solution was added to acetone $(2 \mathrm{~L})$ and the precipitate was filtered and dried over $\mathrm{KOH}$ in vacuo. This dried precipitate $(57 \mathrm{~g})$ was dissolved in pure $\mathrm{H}_{2} \mathrm{O}$ and dialysed against $\mathrm{H}_{2} \mathrm{O}$ in seamless cellulose tubing under agitation for $48 \mathrm{~h}$. The contents of the tubes were freeze-dried to afford $32 \mathrm{~g}$ of flavonoid mixture ( $3 \%$ yield). Chromatography on a Merck Lobar Lichroprep RP-18 (size B) column eluting with $\mathrm{CHCl}_{3} / \mathrm{MeOH}$ gave four fractions: 1-4. Fraction 2 (25 g) was chromatographed and eluted with $\mathrm{H}_{2} \mathrm{O}-\mathrm{MeOH}$ (2:7) to give two fractions, the smaller of which (1.2 g) was further purified by HPLC with $45 \% \mathrm{CH}_{3} \mathrm{CN}$ to give KSR1 (70 mg). The large fraction (19.1 g) was further separated using 50\%, 80\% and $100 \%$ ratios of $\mathrm{H}_{2} \mathrm{O}-\mathrm{MeOH}$. The subfractions were purified by HPLC (45\% $\mathrm{CH}_{3} \mathrm{CN}$ ) to afford KSR2 (60 mg), KSR3 (72 mg) and KSR4 (78 mg).

Hydrolysis of the isolated compounds

A few mg of the glcosides were refluxed with $10 \% \mathrm{HCl}$ in $50 \%$ methanol for $3 \mathrm{hrs}$. The aglycones and sugar fractions were identified by chromatographic comparison with authentic samples. Kamepferol as the aglycone and glucose, rhamnose, and galactose were identified through GC-MS analysis of their alditol peracetate derivatives.

\section{Acetylation of KSR3}

Pyridine (10 mL) and acetic anhydride (10 mL) were added to KSR3 (9 mg). The resulting mixture was heated at $120^{\circ} \mathrm{C}$ for 4 hours after which it was cooled to room temperature. Water was added and 
the solution was extracted with dichloromethane. Evaporation of the solution furnished a residue which was put on the top of a silica gel chromatography column eluted with $\mathrm{CHCl}_{3}-\mathrm{MeOH}-\mathrm{H}_{2} \mathrm{O}$ (30:20:1). The product was further purified by semi-preparative HPLC with $37-38 \%$ B in 30 min to give acetylated KSR3 (4.3 mg).

3'-(3R-acetoxy-5,5-dimethylcyclopent-1-ene)-4'-O-methylscutellarein 7-O-(6"'"-O-acetyl- $\beta$-D-glucopyranosyl-( $1 \rightarrow 3)$-[ $\alpha$-L-rhamnopyranosyl- $(1 \rightarrow 2)]-\beta$-D-glucopyranoside (KSR1). $\mathrm{C}_{45} \mathrm{H}_{56} \mathrm{O}_{23}$, yellow amorphous powder (from MeOH: $\mathrm{D}_{2} \mathrm{O}$ ), mp $227-229^{0} \mathrm{C}$; $[\alpha]_{\mathrm{D}}{ }^{15}-46.9^{0} \mathrm{C}$ (c=0.10; $\mathrm{MeOH}-\mathrm{H}_{2} \mathrm{O}(1: 1)$ ); $\mathrm{UV}_{\max }(\mathrm{MeOH}): 378,344,300$ and $210 \mathrm{~nm}$; IR $v_{\max }(\mathrm{KBr}) \mathrm{cm}-1: 3410,2925,1710(\mathrm{C}=\mathrm{O}), 1656(\mathrm{C}=\mathrm{O})$, 1606, 1502, 1446, 1361, 1178, 1070, 1026; ${ }^{1} \mathrm{H}$ and ${ }^{13} \mathrm{C}-\mathrm{NMR}\left(\mathrm{D}_{2} \mathrm{O}-\mathrm{d}_{2}\right)$ data are listed in Table 1. HRFAB-MS: m/z 987.1515 [M+Na] (calcd. for $\mathrm{C}_{45} \mathrm{H}_{56} \mathrm{O}_{23}$ 964.1533).

Kaempferol-3-O- $\beta$-D-glucopyransoyl-(1 $\rightarrow 4)$ - $\alpha$-L-rhamnopyranosyl-(1 $\rightarrow 6)-\beta$-D-galactopyranoside 7-O-(6"'"-O-acetyl- $\beta$-D-glucopyranosyl-( $1 \rightarrow 3)-[\alpha$-L-rhamnopyranosyl- $(1 \rightarrow 2)]-\beta$-D-glucopyranoside (KSR2). $\mathrm{C}_{53} \mathrm{H}_{72} \mathrm{O}_{35}$, pale yellow paste (from $\mathrm{MeOH}$ : $\mathrm{D}_{2} \mathrm{O}$, mp $207-209^{0} \mathrm{C}$; $[\alpha]_{\mathrm{D}}{ }^{21}-31.1^{0}$, c $=0.48$; MeOH-H ${ }_{2} \mathrm{O}$ (1:1); UV $\mathrm{Unax}_{\text {max }}(\mathrm{MeOH})$ : 374, 345, 302 and $212 \mathrm{~nm}$; IR $v_{\max }(\mathrm{KBr}) \mathrm{cm}-1$ : 3410, 2925, 1721 (C=O), 1606, 1504, 1447, 1359, 1208, 1178, 1086, 1014; ${ }^{1} \mathrm{H}$ and ${ }^{13} \mathrm{C}$ NMR $\left(\mathrm{D}_{2} \mathrm{O}-\mathrm{d}_{2}\right)$ data are given in Table 2 and Table 3. HR-FAB-MS: m/z 1291.3915 [M+Na] ${ }^{+}$(calculated. for $\mathrm{C}_{53} \mathrm{H}_{72} \mathrm{O}_{35}$ 1268.3933)

Kaempferol-3-O- $\beta$-D-glucopyranosyl $(1 \rightarrow 2)-\beta$-D-(6a'-O-caffeoyl)-glucopyranoside 7-O-(6"'"-O-acetyl$\beta$-D-glucopyranosyl-(1 $\rightarrow 3)$-[ $\alpha$-L-rhamnopyranosyl- $(1 \rightarrow 2)]-\beta$-D-glucopyranoside (KSR3). $\mathrm{C}_{56} \mathrm{H}_{68} \mathrm{O}_{34}$, white amorphous powder(from $\mathrm{MeOH}: \mathrm{D}_{2} \mathrm{O}$ ), mp 275-280 ${ }^{0} \mathrm{C}$. $[\alpha]_{\mathrm{D}}{ }^{21}-35.1^{0}$, c $=0.45$; $\mathrm{MeOH}-\mathrm{H}_{2} \mathrm{O}$ (1:1); $U_{\text {max }}(\mathrm{MeOH}): 378,344,300$ and $210 \mathrm{~nm}$; IR $v_{\max }(\mathrm{KBr}) \mathrm{cm}-1$ : 3410, 2925, $1721(\mathrm{C}=\mathrm{O}), 1656$ (C=O), 1606, 1580, 1504, 1447, 1359, 1208, 1178, 1086, 1014, 808, 757, 705; ${ }^{1} \mathrm{H}$ and ${ }^{13} \mathrm{C}$ NMR $\left(\mathrm{D}_{2} \mathrm{O}\right.$, ${ }^{13} \mathrm{C}: 125 \mathrm{MHz} ;{ }^{1} \mathrm{H}: 500 \mathrm{MHz}$ ) data are given in Tables 2 and 3. HR-FAB-MS: m/z 1307.1915 [M+Na] ${ }^{+}$ (calcd. for $\mathrm{C}_{53} \mathrm{H}_{72} \mathrm{O}_{35}$ 1284.3943).

Kaempferol-3-O- $\alpha$-L-(2a',3a'-E-di-p-coumaroyl)-rhamnoside 7-O-(6"'"-O-acetyl- $\beta$-D-glucopyrano-syl$(1 \rightarrow 3)$-[ $\alpha$-L-rhamnopyranosyl-( $1 \rightarrow 2)]$ - $\beta$-D-glucopyranoside (KSR4). $\mathrm{C}_{59} \mathrm{H}_{64} \mathrm{O}_{29}$ Obtained as a white amorphous powder (from MeOH: $\mathrm{D}_{2} \mathrm{O}$ ), mp 284-290 ${ }^{0} \mathrm{C}$. $[\alpha]_{\mathrm{D}}{ }^{21}-33.1^{0}$, c $=0.47$; $\mathrm{MeOH}-\mathrm{H}_{2} \mathrm{O}(1: 1)$; $\mathrm{UV}_{\max }(\mathrm{MeOH}): 378,344,315,300,293,220$ and $210 \mathrm{~nm}$; IR $v_{\max }(\mathrm{KBr}) \mathrm{cm}-1: 3448,2922,1721$ (C=O), 1656 (C=O), 1606, 1580, 1504, 1447, 1359, 1208, 1178, 1075, 833, 808, 757, 705; ${ }^{1} \mathrm{H}$ and ${ }^{13} \mathrm{C}$ NMR $\left(\mathrm{D}_{2} \mathrm{O},{ }^{13} \mathrm{C}: 125 \mathrm{MHz} ;{ }^{1} \mathrm{H}: 500 \mathrm{MHz}\right)$ data are given in Tables 2 and 3. HR-FAB-MS: m/z 1259.3415 [M+Na] $]^{+}$(calcd. for $\mathrm{C}_{59} \mathrm{H}_{64} \mathrm{O}_{29}$ 1236.3543).

\section{Bioassays:}

Nine fungi were used for the bioassays: Aspergillus niger (ATCC 6275), Aspergillus Ochraceus (ATCC 12066), Aspergillus versicolor (ATCC 11730), Aspergillus flavus (ATCC 9643), Penicilium ochrochloron (ATCC 9112), Penicillium funiculosum (ATCC 36839), Trichoderma viride (IAM 5061), Cladosporium cladosporioides (ATCC 13276) and Alternaria alternate (DSM 2006). The strains were obtained from the National Chemical Laboratory (NCL), Pune, India. The micromycetes 
were maintained on malt agar (MA) and the cultures were stored at $+4^{\circ} \mathrm{C}$ and subcultured once a month [35]. To investigate the antifungal activity of the compounds the modified microdilution technique was used [36-37]. The fungal spores are washed from the surface of agar plates with sterile $0.85 \%$ saline containing $0.1 \%$ Tween $80(\mathrm{v}: \mathrm{v})$. The spore suspension was adjusted with sterile saline to a concentration of approximately $1.0 \times 10^{5}$ in a final volume of $100 \mu \mathrm{L}$ per well. The inocula were stored at $+4^{\circ} \mathrm{C}$ for further use. Dilutions of the inocula were cultured on solid MA to verify the absence of contamination and to check the validity of the inoculum.

Minimum inhibitory concentrations (MICs) which inhibited fungal growth, were established by a serial dilution technique using 96-well microliterplates. Extracts of compounds investigated were dissolved in malt medium broth with fungal inoculum to achieve concentrations of $0.03-4 \mu \mathrm{g} / \mathrm{mL}$. The microplates were incubated for $72 \mathrm{~h}$ at $28^{\circ} \mathrm{C}$. The lowest concentrations without visible growth (at the binocular microscope) were defined as MIC. The minimum fungicidal concentrations (MFCs), were determined by serial sub-cultivation of $2 \mu \mathrm{L}$ into microliter plates containing $100 \mu \mathrm{L}$ of broth per well and further incubation for $72 \mathrm{~h}$ at $28^{\circ} \mathrm{C}$. The lowest concentration which killed the $99.5 \%$ of the original inoculum, spores and mycelium of the fungi, was defined as the MFC. Commercial fungicides, miconazole and bifonazole, were used as control $(0.03-5 \mu \mathrm{g} / \mathrm{mL})$. The antimicrobial activity of the compounds against the Gram-Positive bacterial Staphylococcus aureus (ATCC 25923) and Bacillus subtilis BBL 12084, the Gram-negative bacteria Esherichia coli (ATCC 35128) and Pseudomonas aeruginose (ATCC 27853) was evaluated suing the microdulution technique. Streptomycin (solution of $1 \mathrm{mg} / \mathrm{mL}$ in $\mathrm{H}_{2} \mathrm{O}$ ) was used as standard form the antibacterial activity.

\section{References}

1. Kaul, M.K. Medicinal Plants of Kashmit and Ladakh; Indus Publishing Co.: New Delhi, 1997; p. 144.

2. Nandkarni, A.K. Indian Materia Medica; Popular Book Depot: Mumbai, 1954; p. 1108.

3. Chopra, R.N.; Nayar, S.L.; Chopra, I.C. Glossary of Indian Medicinal Plants; Publication and Information Directorate: New Delhi, 1956; p. 222.

4. Kirtikar, K.; Basu, B.D. Indian Medicinal Plants; Lalit Mohan Basu: Allahabad, 1993; p. 1420.

5. Sarin, Y.K. Illustrated Manual of Herbal Drugs Used in Ayurveda; CSIR \& ICMR: New Delhi, 1996; p. 62.

6. Chang, M.S; Wan, J.S; Ming, J.D.; Jang, J.L.; Gum, H.L. Cytotoxic Sesquiterpene Lactones from the Root of Saussurea lappa. J. Nat. Prod. 2003, 66, 1175-80.

7. Pai, P.P.; Kulkarni, G.H. Isolation of $\alpha$-amyrin sterate, $\beta$-amyrin and lupeol palmitates from the costus leaves. Curr. Sci. 1997, 46, 261-62.

8. Bruno, M.; Gunther, O. (E)-9-isopropyl-6-methyl-5,9-decadiene-2-one, a terpenoid $\mathrm{C}_{18}$-ketone with a novel skeleton. J. Chem.Soc. 1997, 353-54.

9. Singh, I.P.; Talwar, K.K.; Arora, J.K.; Chhabra, B.R.; Kalsi, P.S. A biologically active guaianolide from Saussurea lappa. Phytochemistry 1992, 31, 2529-31.

10. Talwar, K.; Singh, I.P.; Kalsi, P.S. A sesquiterpenoid with plant growth regulatory activity from Saussurea lappa. Phytochemistry 1992, 31, 336-38. 
11. Yoshikawa, M.; Hatakeyama, S.; Inoue,Y.; Yamahara, Saussureamines A, B, C, D, and E, new anti-ulcer principles from Chinese Saussureamines Radix. J. Chem. Pharm. Bull. 1993, 41, 21416.

12. Kalsi, P.S; Kumar, S; Jawanda, G.S.; Chhabra, B.R. Guaianolides from Saussurea lappa. Phytochemistry 1995, 40, 1713-15.

13. Dirk, C.A; Renee, J.G.; Soren, R.J.; Fevi, O; Nigel, C.V. Acylated flavone glycoside from Veronica. Phytochemistry 2003, 64, 1295-01.

14. Kemp, W. Organic Spectroscopy; MacMillan: London, New York, 1991; pp. 66, 194.

15. Mohamd A. Techniques in Terpenoid identification; Birla Publication: New Delhi, 2001; p. 176.

16. Tuchinda, P; Udhcacho, J.; Reutrakul, V.; Santisuk, T.; Skeleton, B.W.; White, A.H.; Taylor, W.C. Pimarane Diterpenes from Kaemperia. Phytochemistry 1994, 36, 731-34.

17. Nasser, A.; Singh, B. Acetylated flavonol triglycosides from Ammi majus L. Phytochemistry 1998, 49, 2177-2180.

18. Emam, A.M.; Elias, R; Maussa, A.M.; Faure, R.; Debrauwer, L.; Balansard, G. Two flavonoid triglycosides from buddleja madagascariensis. Phytochemistry 1998, 48, 739-42.

19. Joao, F.; Castelao, J.R.; Otto, R.G.; Robexto A.D.; Antonio, A.L.M. Xanthonolignoids from Kielmeyera and Caraipa Species ${ }^{13} \mathrm{C}-\mathrm{NMR}$ spectroscopy for Xanthones. Phytochemistry 1977, 16, 735-40.

20. Amaro-Luis, J.M.; Moser, J.; Yuen, D.A.; Larsen, T.B.; Matyska, C.; Li T.-M.; Li W.-K.; Yu J.G. Flavonoids from Artabotrys Hexapetalus. Phytochemistry 1997, 45, 831-33.

21. Nkengfack, A.E.; Fomum, Z.T.; Ubillas, R.; Sanson, D.R.; Tempesta, M.S. Extractives from Erythrina Eriotrocha. J. Nat. Prod. 1990, 53, 509-12.

22. Saracoglu, I.; Varel, M.; Calis, I.; Donmez, A.A. Neolignan, Flavonoid, Phenylethanoid and Iridoid Glycosides from Phlomis intergrigolia. Turk. J. Chem. 2003, 27, 739-47.

23. Agrawal, P.K. NMR Spectroscopy in the structural elucidation of oligosaccharides and glylcosides. Phytochemistry 1992, 31, 3307-30.

24. Voutquenene, L.; Kokougan, C.; Lavad, C.; Pouny, I.; Litaudon, M. Triterpenoid Saponins and acylated prosapogenins from Harpullia Ausro Caledonica. Phytochemistry 2002, 59, 825-832.

25. Alexander, S.S.; Nikolay, E.N.; Vera, Yu. A.; Nikolay, K.K. ${ }^{1} \mathrm{H}$ and ${ }^{13}$ C-NMR data for 2-O-, 3O- and 2,3-Di-O-glycosylated methyl $\alpha$ - and $\beta$-D-glucopyranosides and $\beta$-D-galactopyranosides. Mag. Res. Chem. 1993, 31, 599-613.

26. He, Z.; Qiao, C.; Han, Q.; Wang, Y.; Ye, W.; Xu, H. New Triterpenoid Saponins from the roots of Platycodon Grandiflorum. Tetrahedron 2005, 61, 2211-2215.

27. Bradbury, H.; Jenkins, J. Determination of the Structure of Trisaccharides by ${ }^{13} \mathrm{C}-\mathrm{NMR}$ Spectroscopy. Carbohydr. Res. 1984, 126-156.

28. Harborne, J.B.; Mabry, T.J. The Flavonoids: Advances in Research; Chapmann \& Hall: London, New York, 1982.

29. Bloor, S.J.; Bradley, J.M.; Lewis, D.H.; Davies, K.M. Identification of flavonol and anthocyanin metabolites in leaves of Petunia Mitchell and its LC Transgenic. Phytochemistry 1998, 49, 142730.

30. Miyase, T.; Iwata, Y.; Ueno, A. Tenuifolioses G-P. Oligosaccharide multi-esters form the roots of poygalatenuifolia willd. Chem. Pharm. Bull. 1992, 40, 2741-2748. 
31. Komori, T.; Ida, Y.; Mutou, Y.; Miyahara, K.; Nohara, T.; Kawasaki, T.; Mass spectra of spirostanol and furostanol glycosides. Biomed. Mass Spectrum. 1975, 2, 65-77.

32. Tomas-Barberan, F.A.; Gil, M.I.; Ferrenres, F.; Tomas-Lorente, F. Flavonoid P-Coumaroyl and 8-hydroxyflavone Allosylglucosides in Some Labiatae. Phytochemistry 1992, 31, 3097-3102

33. Fiorini, C.; David, B.; Fouraste, I.; Vercauteren, J. Acylated Kaempferol Glycosides from Laurus nobilis leaves. Phytochemistry 1998, 47, 821-25.

34. Aritomim, M.; Kawasaki, T. Three Higly Oxygenated Flavone Glucuronides in Leaves of Spinacia oleracea. Phytochemistry 1984, 23, 2043-47.

35. Booth, C. Fungal Culture Media. In: Methods in Microbiology; Academic Press: London, New York, 1971; pp. 49-94,

36. Hanel, H.; Raether, W. A more sophisticated method of determining the fungicidal effect of water insolube preparations with a cell harvester, using miconazole as an example. Mycoses 1988, 31, 148-54.

37. Daouk, R.K.; Dagher, S.M.; Sattout, E.J. Antifungal activity of the Essential oil of Origanum syriacum L. J. Food Prot. 1995, 58, 1147-49.

Sample Availability: Very small samples are available from the authors.

(C) 2007 by MDPI (http://www.mdpi.org). Reproduction is permitted for noncommercial purposes. 